\title{
life skills for athletics students
}

\section{Dr. Atef Sayed Ahmed . sadat city university .}

\section{Introduction :}

Life skills are the abilities for adaptive and positive behaviour, that enable individuals to deal effectively with the demands and challenges of everyday life. (World Health Organization , 1997)

There are several reasons why sport is a suitable context for teaching life skills and many of the skills learned in sport are transferable to other life domains.

There is a resemblance between performance in sport and personal in life and an apparent similarity between the mental skills needed for successful performance in sport and in non-sport domains (Danish, Forneris, \& Wallace, 2005).

Sport skills and life skills are learned in the same way.(Orlick \& McCaffrey, 1991).

The Life skills are contents of the Decision making - problem solving, Creative thinking - critical thinking , Communication - interpersonal relationships, Self-awareness - empathy and Coping with - emotions stressors.

Complementary Life skills can be paired to reveal 5 main life skills “ areas ", as shown below . For health promotion , teaching skills in each of these areas provides a foundation in generic life skills for psychosocial competence . (World Health Organization , 1997 )

Athletics form an essential and important part of the Olympic Games and all major athletics championships .Athletics include many events, which are varied and differ in performance, physical and physiological requirements . (Harald Muller, Wolfgang, Ritzdorf, 2009)

So athletics are essential in the curriculum in the faculty of physical education in different study phases.

The second year student In faculty of physical education Sadat City University, studies hurdles, High jump and Discus throwing events in athletics curriculum. These events require the motor skills and technical performance. 
Because of the nature of the environment in which the Faculty of Physical education University Sadat City located, which is characterized by the agricultural nature ,this may affect the level of performance in athletics events for the students .By analysing the performance of national athletes coming from similar environment the researcher found that there is an environmental effect on their performance(EL-Fayoum city in race walking, EL-Mahalah city in throwing events,AL-Sharqia city in jumping events)

In this study researcher believes that by studying life skills for students and their relationship to the level of performance and achievement in hurdles , High jump and Discus throwing events, This may be an indicator to identify the talented student in the Faculty of Physical education University Sadat City in this events .

\section{The research aims to:}

- Determinate the life skills levels for students in faculty of physical education Sadat city university .

- Determinate the performance levels (hurdles, High jump and Discus throwing events ) and achievement for students in faculty of physical education Sadat city university .

- Identify the Relationship between life skills , performance and achievement in athletics curriculum for faculty of physical education Sadat city university students.

\section{Methods :}

The researcher used survey method by analysing the questioner of life skills and performance in athletics curriculum for faculty of physical education Sadat city university students.

\section{Sample :}

The sample included 150 students at the stage two in faculty of physical education - sadat city university, ( age $19.780 \pm 0.578$ years ) (body height176.300 $\pm 6.737 \mathrm{~cm}$. ) (body mass73.220 $\pm 9.706 \mathrm{Kg}$. )

\section{The life skills Questionnaire :}

The researcher used The life skills questionnaire design by El Haike, El Bataina ( 2007 ) , The researcher re- legalization of the questionnaire on the research community, The life skills questionnaire consisted of 66 items that Supplies to the questionnaire component which is physical, skill, Communication, social skills and team work, Self-awareness - sympathy, Creative thinking , and critical thinking. Coefficient ranged of life skills questionnaire ( $0.805: 0.941)$, Reliability coefficient ranged ( $0.835: 0.892$ ). 


\section{Achievement test}

The researcher design The achievement test consisted of 45 items that Supplies to the questionnaire component which is History, Technique , Teaching and Law, Also it is taken into account in the formation of the questionnaire that includes the knowledge and understanding, Mental skills, professional and practical skills, Public and movable skills, in the athletics curriculum in the second year the student study the hurdles, High jump and Discus throwing events. Coefficient ranged of achievement test $(0.741: 0.893)$, Reliability coefficient ranged ( $0.793: 0.834)$.

\section{Performance skill test :}

The performance test is a level of performance skill in the last practical exam for students at the end of first term at 2015 for students of the second year in faculty of physical education - Sadat city university . the athletics curriculum in the second year the student study the hurdles, High jump and Discus throwing events .

\section{Results :}

Table 1 : Mean, standard deviation, Total Estimated, Ratio and ranking of the life skills Questionnaire for students of the second year in faculty of physical education - Sadat city university

\begin{tabular}{lcccccc}
\hline & No. & X & SD & $\begin{array}{c}\text { Total } \\
\text { Estimated }\end{array}$ & $\%$ & Ranking \\
\hline physical and skill & 12 & 33.840 & 2.137 & 5016 & 94.00 & 1 \\
\hline Communication & 12 & 33.100 & 2.351 & 4965 & 91.94 & 4 \\
\hline Social skills and team work & 14 & 38.800 & 3.102 & 5820 & 92.38 & 2 \\
\hline Self-awareness - empathy & 14 & 38.620 & 3.095 & 5793 & 91.95 & 3 \\
\hline Creative thinking - critical thinking & 14 & 38.100 & 3.625 & 5715 & 90.71 & 5 \\
\hline Total life skills & 66 & 182.460 & 10.360 & 27309 & 91.95 & \\
\hline
\end{tabular}




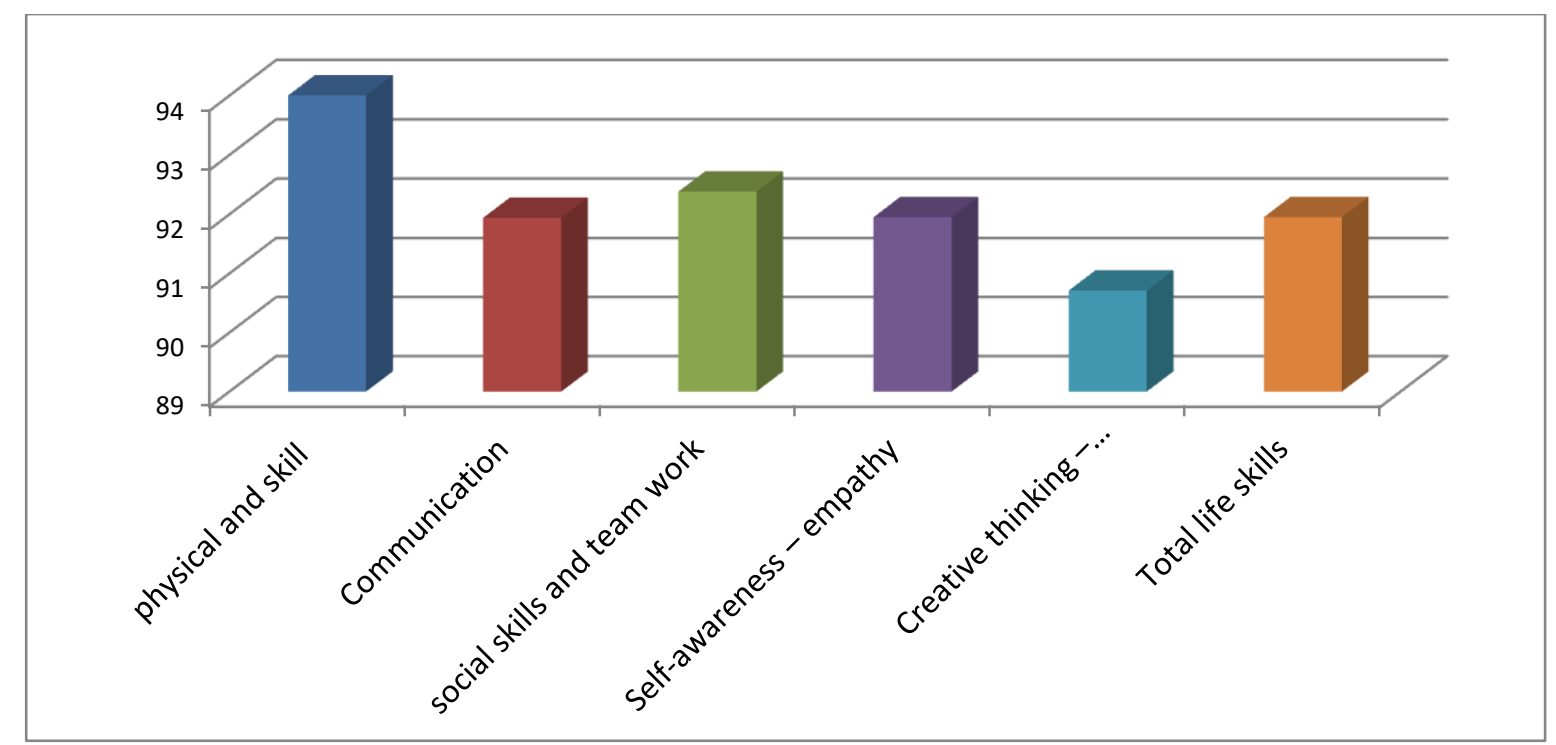

Figure 1: Characteristics of component of the life skills Questionnaire .

Table 2 : Mean, Standard deviation and correlation between the life skills Questionnaire, level of performance skill in athletics for students of the second year in faculty of physical education - Sadat city university .

\begin{tabular}{|c|c|c|c|c|c|c|c|c|c|c|}
\hline & $x$ & SD & Perf. & Achif. & 1 & 2 & 3 & 4 & 5 & Total \\
\hline Performance skill & 31.580 & 4.633 & & $.571^{\star \star}$ & $.251^{\star \star}$ & -.144 & $.164^{*}$ & $.337^{\star *}$ & $.200^{*}$ & $.239^{* *}$ \\
\hline Achievement & 36.340 & 4.557 & & & .099 & -.065 & .130 & $.309^{* *}$ & $.215^{\star \star}$ & $.212^{* \star}$ \\
\hline physical and skill & 33.840 & 2.137 & & & & .107 & $.293^{* \star}$ & .116 & $.608^{* \star}$ & $.566^{* *}$ \\
\hline Communication & 33.100 & 2.351 & & & & & $.483^{* *}$ & $.346^{* *}$ & $.261^{* *}$ & $.588^{\star *}$ \\
\hline social skills and team work & 38.800 & 3.102 & & & & & & $.573^{* *}$ & $.568^{* *}$ & $.839^{* *}$ \\
\hline Self-awareness - empathy & 38.620 & 3.095 & & & & & & & $.387^{\star \star}$ & $.708^{* *}$ \\
\hline Creative thinking - critical thinking & 38.100 & 3.625 & & & & & & & & $.820^{* *}$ \\
\hline Total life skills & 182.460 & 10.360 & & & & & & & & \\
\hline
\end{tabular}

$$
\mathrm{P}<0.05
$$




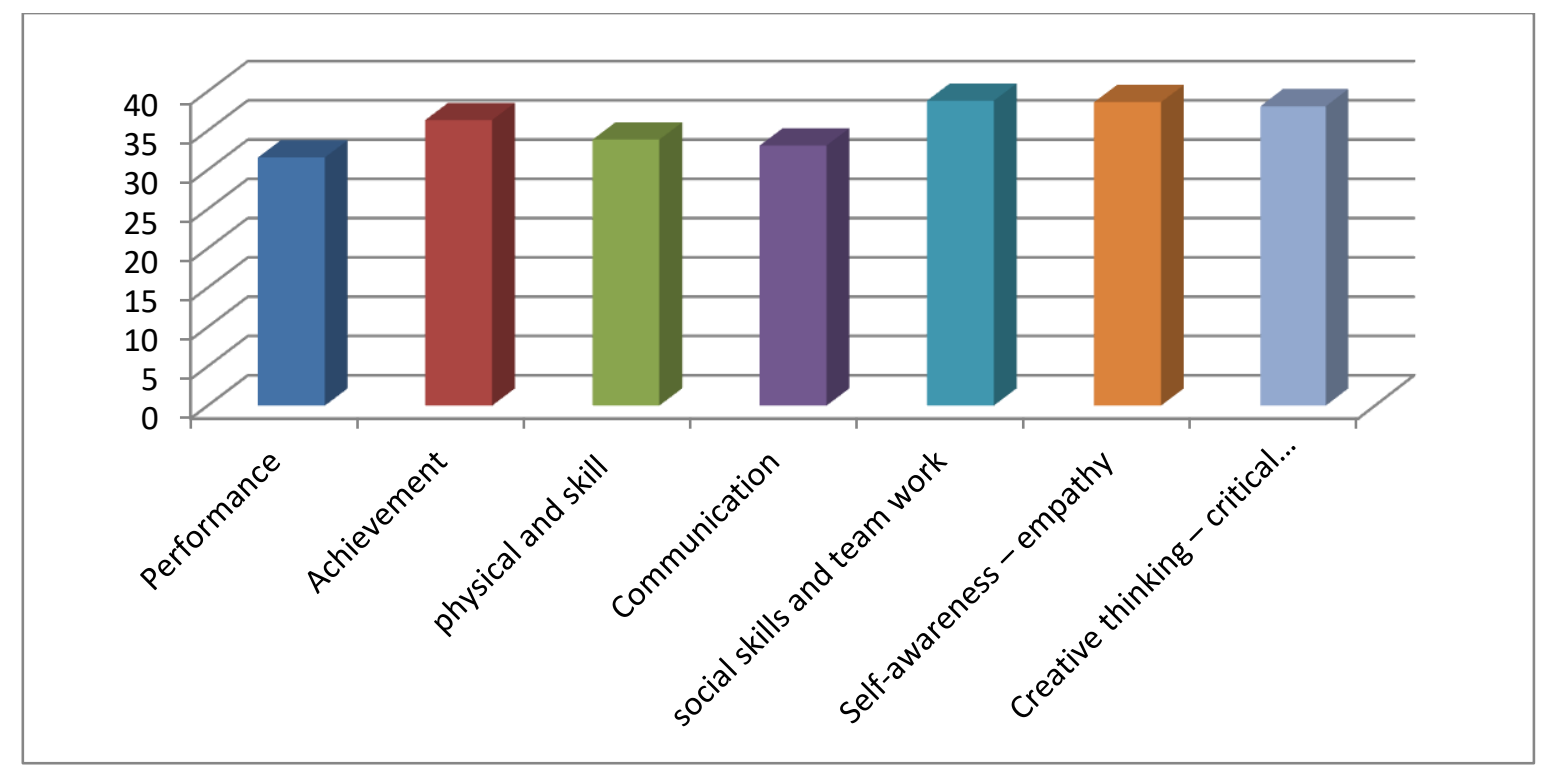

Figure 2: Characteristics means of component of the life skills Questionnaire, performance skill .

\section{Discussion :}

The purpose of this investigation was to rank the life skills and correlation with the achievement and performance in some athletics events for students .

By analyzing Table 1, it can be concluded that first; ( physical and skill), The researcher declared a need for performance and skill in the study due to the fact that students pay attention to physical performance . second ; (social skills and team work ) Team work is one of the needs for the students in the study to help in education, especially in some of the athletics competitions which require cooperation with the colleague and team work , third ; (Self-awareness sympathy), includes recognition of 'self', our character, our strengths and weaknesses, desires and dislikes. Developing self-awareness can help us to recognize when we are stressed or feel under pressure. It is often a prerequisite to effective communication and interpersonal relations, as well as for developing sympathy with others., fourth ;(Communication), means that we are able to express ourselves, both verbally and non-verbally, in ways that are appropriate to our cultures and situations. This means being able to express opinions and desires, and also needs and fears. And it may mean being able to ask for advice and help in a time of need, Sharon K. Lanning, Tegwyn H. Brickhouse, John C. Gunsolley, Sonya L. Ranson, Rita M. Willett ( 2011 ) . fifth; (Creative thinking - critical thinking), helps us to deal constructively with decisions about our lives. This can have consequences for health. It can teach 
people how to actively make decisions about their actions in relation to healthy assessment of different options and, what effects these different decisions are likely to have. WHO (world health organization ) (Danish, Forneris, \& Wallace, 2005), Marios Goudas ( 2010 ) .

By analyzing Table 2, we can conclude the correlation between life skills (the physical and skill, Self-awareness - sympathy and Creative thinking critical thinking, total life skills ) and level of performance skill for students . And we can conclude the correlation between the life skills ( Self-awareness empathy and Creative thinking - critical thinking, total life skills ) and achievement in athletics for students .

The researcher clarify that the Positive relationship between life skills, level of performance and achievement in athletics curriculum for faculty of physical education Sadat city university students, May be to the favour of athletics requirement as( the skill and physical skills for hurdles, High jump and Discus throwing events,) because this events requires a High performance, speed, power and flexibility in addition to general coordination and tempo for triple step between hurdles, this skills can be improved by organizing of the life skills, so that life skills improving the general sports skills and the physical fitness.

High jump requires optimum speed to approach, as well as, muscle power, which enables the student 's good take off to pass the bar, and flexibility for back to pass the bar and general coordination of the body .

Discus throwing skill requires muscle strength, agility and balance , good thinking and perception of the performance. life skills may provide some factors that help the students in the completion of the other athletics events .

Athletics requires thinking skills through performing and require the student to perform the skill, what is the thinking about?, what will be made? that is the first step in education. ( B. Yazdanpanah, M. Safari , F. Vafaei, K. Zandi ( 2015 ).

Life skills include psychosocial competencies and interpersonal skills that help people make informed decisions, solve problems, think critically and creatively, communicate effectively, build healthy relationships, sypathize with others, and cope with managing their lives in a healthy and productive manner. Mark E. Courtney, JoAnn Lee, Alfred Perez ( 2011 ), Daniel Gould, Yongchul Chung, Paige Smith, Jackie White ( 2006 ) 


\section{Recommendations :}

- Measuring the level of Life skills of the students .

- Development of life skills among students, They help students in the level of performance in athletics events.

- Increase awareness among students of the importance of contact with others.

- Development of teamwork among students .

\section{References}

B. Yazdanpanah, M. Safari , F. Vafaei, K. Zandi ( 2015 ) . Life skills education of rural families in Iran:a community-based participatory study . journal homepage: www.elsevier.com/puhe . p u b 1 i c health $129,587-590$.

Daniel Gould, Yongchul Chung, Paige Smith, Jackie White ( 2006 ) . Future Directions in Coaching Life Skills: Understanding High School Coaches' Views and Needs , athletic insight the online journal of sport psychology , September, 2006 , Volume 8, Issue 3 .

Danish, S., Forneris, T., \& Wallace, I. (2005). Sport-based life skills rogramming in the schools. Journal of Applied School Psychology, 21(2), 41-62.

El Haike , El Bataina ( 2007 ) . The extent of the employment life skills curriculum in the College of Physical Education Yarmouk University, International Scientific Conference II. Scientific developments in physical education and sport . Faculty of Physical Education, Yarmouk University.

Harald Muller, Wolfgang, Ritzdorf ( 2009 ) . Run! Jump! Throw! - IAAF releases the latest version of the respected CECS book of Athletics techniques .

Marios Goudas ( 2010 ). Prologue : a review of life skills teaching in sport and physical education . Hellenic journal of psychology, Vol. 7 , PP $241-258$.

Mark E. Courtney , JoAnn Lee , Alfred Perez ( 2011 ) . Receipt of help acquiring life skills and predictors of help receipt among current and former foster youth . journal homepage: www.elsevier.com/locate/childyouth . Children and Youth Services Review 33, 2442-2451

Orlick, T., \& McCaffrey, N. (1991). Mental training with children for sport and life. The Sport Psychologist, 5, 322-334.

Sharon K. Lanning, Tegwyn H. Brickhouse, John C. Gunsolley, Sonya L. Ranson , Rita M. Willett ( 2011 ) . Communication skills instruction: An analysis of self, peer-group, student instructors and faculty assessment . journal 
homepage: www.elsevier.com/locate/pateducou . S.K. Lanning et al. / Patient Education and Counseling 83, 145-150 .

World Health Organization ( 1997 ) . Life skills education for children and adolescents in schools, Introduction and Guidelines to Facilitate the development and implementation of life skills programmes, Programme on Mental Health. Geneva p.2, 3 . 